\title{
Moral Aspects of Laity in the Organization of the Roman and Catholic Church*
}

\section{Introduction}

The laity in the Catholic Church means the same as laypeople who have no special holy orders within the organization, except two sacraments, namely: Holy Baptism and the Holy Confirmation, which, applying in the soul of man an indelible mark (the sacramental character), thereby give him an absolute mission to fulfil ${ }^{1}$. By mentioning the moral aspects of the laity, we would like to point out that we disregard discussing in this place the special structure that it might have in the future of the Catholic Church. This side of the laity is one of the constitutive elements of the Church; its explanation and determination, therefore, belong to the teaching of the Church ${ }^{2}$. We are interested in the question of whether the laity, laypeople in the Church, as a numerically dominant part of the People of God, regardless of its substantial or specific form of existence in the organization of the Catholic Church, has a special, to some extent self-fulfilling mission to comply, or is it only •- as one of the lay auditors at the Council expressed himself - a bridge between the church (probably in the sense of Hierarchy) and the rest of the world.

* STV 5(1967)1. Paper presented at Ecumenical Week in Warsaw, November 1964.

1 LG 31. Cf. P. Dabin, Le sacerdoce royal des fideles, Paris 1941, 201ff, 314ff, 314ff; Y. Congar, Jalons pour une theologie du laicat, Paris 1953, 498ff, 529ff; R. Poelman, Peuple de Dien, "Lumen vitae" 3 (1965), 454f.

2 Cf. P. Dabin, op. cit., 7ff. 


\section{Mission of the Laity}

If, however, the laity has a special mission to fulfil in the world then the realization of this mission implies a right action not only physically but also above all morally because it is about the participation of laypeople in the work of the salvation of the world. Speaking, therefore, of the moral aspects of the laity, i.e., its dynamic side, we take into account the role of laypeople in carrying out the mission of the entire Catholic Church around the world.

No matter how this role was understood in the Church over the past centuries, - today, when the world shimmers with Christianity, more and more, people distance themselves away from God in many aspects, becoming only in a more refined manner, because it is supposedly "scientifically" justified, similar to the people whom the Apostles of Christ carried the good news, - today, when one often hears about the need to re-read the Gospel of Jesus Christ, not elsewhere, but in the sources of Revelation, one should look for basic notions about the role of the laity in the organization of the Catholic Church ${ }^{3}$.

Certain notions about the future and mission of the Church, and thus the laity, have already been left by Christ in His parables, as in the parable of the mustard seed and the yeast ${ }^{4}$.

The first of these parables is a prophetic vision of the Church's profound growth in space and time, the second of which seems to relate primarily to the total control of the soul by grace. The thought of the real attitude of the Church's mission to a universal extent is suggested by Christ's parable of the good shepherd. "I am a good shepherd, says Christ... I know my sheep, and my sheep know me" - it is a constituted sheep-flock. However, here the good Shepherd has more to say: "I have other sheep that are not of this fold. I must bring them in as well, and they will listen to My voice. Then there will be one flock and one shepherd" 5 . For many contemporary Catholics, the full meaning of these words of Christ made a mark, perhaps, only when one saw in nature or on television, learned from the radio or the press about the great variety of continents, us, nations, represented by the gathering of participants of the Second Vatican Council. In the meantime, this saying of Christ about other sheep was only a consequence of the fact that the Word became flesh, that the Son of God became a man only without any specifically emphasized local, racial or national

\footnotetext{
Chapter IV of LG is instructive in this respect: De laicis, 37ff. Mt 13:31-35.

J 10:14.16.
} 
qualifications ${ }^{6}$. This fact is the visible basis of His power over all human flock. Therefore, in the missionary mandate before his ascension, Christ only confirms this truth when He speaks these words: "All authority in heaven and on earth has been given to me. Therefore, go and make disciples of all nations, baptizing them in the name of the Father and of the Son and the Holy Spirit... And surely, I am with you always, to the very end of the age."

From the words of Christ, it appears that God's will is for the Church to reach the whole of humanity with its influence. It would be the fulfilment of the parable of the mustard seed. However, it seems that the normal condition for realizing that God intends to preserve the truth contained in the Parable of the Leaven, "a woman took and hid in three measures of flour until it was all leavened." 8 The point is, therefore, that God's power will penetrate the depths of people declaring their belonging to Christ. This applies not only to clerics but also, and above all, to lay Catholics. The test of the effectiveness of the teachings of God given to the listeners is the dynamic acceptance of them, by them. The role of the laity in the Church means not a passive attitude towards the missions of the Church of Christ ${ }^{9}$, but exceedingly active one that Christ mentions when He speaks: "Let your light shine before others, so that they may see your good works and give glory to your Father who is in heaven." ${ }^{\text {"10 }}$ Laity, therefore, somehow must contribute to the growth of mustard seeds into a powerful plant or even a tree and become a leaven of access to God for all humankind. Before that, however, one must feel responsible for this work ${ }^{11}$. The idea is that previously subjected to the action of the leaven of the Gospel, in turn, became leaven in the modern world, giving witness to Christ with their own lives ${ }^{12}$. This would indicate that the mission of the laity in the organization of the Church is primarily of a moral, dynamic, practical nature. "Above all" however, does not mean "entirely." The fact that at the Second Vatican Council, as each session followed, the number of female and male lay auditors also grew, demonstrating

6 Cf. M. Lagrange: Evangile selon Saint Jean, Panis 1925, Introduction, CXLIV; $280 f$.

7 Mt 28:18-20. Cf. Cl. Filion, La sainte Biblie, vol. 7, Paris 1925, $191 \mathrm{f}$.

$8 \quad$ Mt 13:33. Cf. S. Thomae Aquinitis, Catena aurea in Quatuor Evangelia, Taurini 1915, vol. $1,237$.

9 Cf. R. Muller, Der Laie in der Kirche, TQ 130 (1950), 184ff; N. Rocholl, Vom Laienpriestertum, Paderborn 1940, 94.

10 Mt 5:16. Cf. S. Thomae, Catena aurea..., op. cit., 80ff; R. Poelman, Peuple de Dieu, "Lumen vitae" 3 (1965), 460ff, 476ff.

11 LG 37. Cf. A. Carre, Le sacerdoce des Laics, Paris 1960, 149ff, 157ff.

12 LG 31.34. Cf. G. Delcuve, Faut-il encore annoncer l'Evangile?, "Lumen vitae" 3 (1965), $513 \mathrm{ff}$. 
that in some cases, when it comes to the introduction of the principles of the Gospel and even of the natural law, secular participation becomes in some sense indispensable ${ }^{13}$. It is known that, for example, the issues of Scheme XIII require the cooperation of entire groups of scientists: biologists, physicians, sociologists, psychologists, etc. in order for the Church to decide on some matters in a way that most closely matches the needs of the age of humanity, while at the same time keeping God's creative concept unchanged.

\section{Content and Scope of the Mission of the Laity}

However, despite the precious contribution of the laity to the work of renewing the Church and adapting the work to the requirements of the present, the above activities of the laity include, for understandable reasons, only a small group of laypeople. In the meantime, the laity in God's intentions and the understanding of the Church of the preacher are all Christ's followers living in the world, and therefore not separated from the life of this world, from its progress or decadence. In any case, laity means laypeople living in Christianity in the world as is, at the given moment ${ }^{14}$.

However, it is not clear what the moral aspect of the laity as a whole of lay Catholics in the world expresses. For a while an intellectual elite may be an irrevocable help to the Hierarchy in solving some of the doctrinal or practical problems that have already arisen as a result of the progress of the natural sciences, changes in the living conditions of people on earth, the entire laity will always be below this level. This circumstance, however, does not exacerbate the situation in the Church. It will not be a mistake when one says that the laity, as a whole, in the words of Saint Peter the Apostle, is "a royal priesthood, a holy people, a nation belonging to God." ${ }^{15}$ For this reason, the laity, in this sense, is somehow related to the issue expressed by Christ on missionary leave.

In fact, the verbal function of Gospel teaching was entrusted to him, with small exceptions, to the Apostles and their successors, bishops, and priests. We know, however, what were the results of this teaching, if it does not become a leaven of creative change for the better, especially in the life attitude and practice of the laity. Moreover, the fact is that at the present moment, the Church, based on the details of Revelation, has matured in the conviction that

13 LG 33.

14 LG 36.

15 STV (1967)1. 
the laity who implements the principles of the Gospel in his secular life is an indispensable element of the salvific work of the Church as a whole, that is, the Hierarchy along with the laity ${ }^{16}$.

There is a Latin saying, verba docent, exempla trahunt - words instruct, illustrations lead. One should not think that saying in places, times, ways, means of action, etc., in particular circumstances, refers mainly to the Hierarchy, the clergy. Even tens of thousands of bishops and priests and several hundred thousand monks and nuns do not constitute a large number of Good News sowers against more than three billion people living on the globe. However, nearly six hundred million Catholics and several hundred million Christians of other religions are already a substantial number in the apostolate of the true God in the world.

\section{Moral Aspects of the Laity}

It is not an exaggeration to say that the laity has a particular independent function to fulfil in the Church, namely teaching through example, attracting others to Christ through a full Christian life on a daily basis ${ }^{17}$. Life, on the other hand, is not an abstraction from authentic human life in the world, for it consists of both family life, as well as work on a farm, in a factory, in an office or school, in a hospital or in the theatre, etc. ${ }^{18}$ So this is an honestly and comprehensively human life, with the holy light shining upon the grace of God's supernatural childhood, which St. John the Apostle in his first catholic letter speaks about ${ }^{19}$. Because the truth about this eldritch grace applies to all people, for God has called everyone to the Holy order, regardless of whether the call was completed in someone, whether it is a state of nearer or further potency for many, we can imagine how capable it is to change our attitude towards other people. Since God is the Father of us all, we are all brothers, regardless of the place we occupy on the globe, the colour of our skin or belonging to this or another nation.

The reality of God's fatherly economy for people should penetrate to the consciousness of the laity, in order to become the driving force of its proper functioning in the Church. Specifically, it is enough for lay Catholics to realize

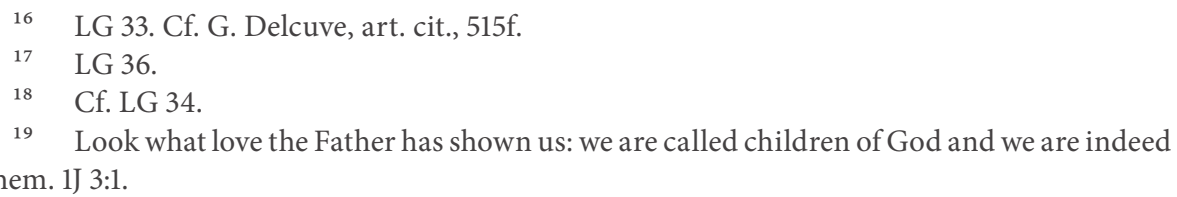


their direct earthly goals in their various ways of life and daily work, guided by the light of faith and inseminated with love towards God and all people. ${ }^{20}$ This is indeed a great acronym in terms of Christian life, but it contains rich content. Love, especially the supreme, which Saint Thomas Aquinas describes as friendship with God, and the God of all people made in His image and likeness, may be the impulse of the most diverse activities. Before that, however, it unites all Christians into one great loving family. In the Acts of the Apostles, the first history of the Church of Christ, Saint Luke points out that "many believers had one heart and one soul, and none of them had their own name but they shared everything." ${ }^{21}$ With the right proportion to the needs of present times and the changed living conditions in which mankind found itself in twenty centuries after Christ is coming into the world, this way of behaving of the original Christians is to become the norm of conduct of the contemporary laity in the Church. It will be proof of mission fulfilment through him.

In the first letter to the Thessalonians, St. Paul the Apostle writes that the Thessalonians, for their part, became followers of (Paul) and Christ, accepting the word, despite all the aggravations, with the joy of the Holy Spirit. In this way, they became an example for all believers in Macedonia and Achaia. Furthermore, the Apostle of Nations clearly indicates that the word of the Lord, having come out from them, resounded not only in Macedonia and Achaia but that the news of their faith in God has come everywhere and to the extent that - "we do not need to talk about it anymore." 22

Then follows the enumeration of deeds, the source of which was the belief in the true God accepted by the Thessalonians.

By translating the above into the modern Christian language, one could say that although it is true that faith is the indispensable foundation of authentic Christian life, its vitality is demonstrated only by the implementation of its principles. This vitality of the faith of the laity may sometimes $\bullet-$ as in Thessalonians - even release Hierarchy from excessive effort in verbal teaching. For the behaviour and actions of its followers will speak in a victorious way for the truth of God as the object of faith, and for its necessity for the development of a thoroughly humanistic life here on earth and for the happiness of future life.

22 1Tes 1, 6-8. Cf. Cl. Fillion, op. cit., 428f. 


\section{Vital Aspects of the Laity}

The manifestations of the vitality of the supernatural faith are the different facts made by its followers. What are these facts, Christ himself points out, describing the upcoming final judgment over people. Then He will tell the righteous: "For I was hungry, and you gave me food; I was thirsty, and you gave me drink; I found myself in exile, and you received me; I was naked, and you clothed me; I was sick, and you visited me; I was in prison, and you came to me." ${ }^{23}$ When asked, when it was, He will answer: "Truly I tell you: Whatever you did for one of the least of these brothers of Mine, you did for Me"24. Here is the effect of the laity; the will of Christ is clear: there must be facts. For "as the body without a spirit is dead, so also faith without works is dead." ${ }^{25}$

The applicability of this program in present times is not necessarily to be manifested only in the form of deeds of mercy, of which we have referred. Present times, without changing motives or goals of action, require a broader approach to this matter. Today, nakedness, hunger, thirst, homelessness, illness, and slavery are not covered by individuals, but whole nations, millions and hundreds of millions of people. Therefore, the forms of coming to them with the help of different ones should have features. However, to avoid this, if the Gospel of Jesus Christ is to become the constitution of Christian life then it is down to the laity. Above all, it is because the clergy and the nature of its vocation and the spirit of the times do not seem to become too involved in activities that require from Christian nations both significant technical preparation and enormous capital and hands to implement large-scale assistance ${ }^{26}$.

This is the contemporary form of the apostolate of the laity, but the soul of her are the words of Christ the Judge contained in the above-cited answer:

$\begin{array}{ll}23 & \text { Mt 25:35-36. } \\ & \text { Mt, 25:40. } \\ & \text { Jak 2:26. } \\ & \\ & \text { The words of the above-mentioned Dogmatic Constitution on the Church are significant }\end{array}$

26 The words of the above-mentioned Dogmatic Constitution on the Church are significant igitur in profanis disciplinis compe- tentia suaąue activitate, gratia Christ! intrinsecus elevata, valide con- ferant operam, ut bona creata secundum Creatoris ordinationem Eius- que Verbi illuminationem humano labore, arte technica civilique cul- tura ad utilitatem omnium prorsus hominum excolantur, aptiusąue inter illos distribuantur, et suo modo ad universalem progressum in humana et Christiana libertate conducant. Ita Christus per Ecclesiae membra totam societatem humanam suo salutari lumine magis magis- que illuminabit”. Const. 41-42, s. 36. Por. L. Hoang Gia Quang, Une Eglise cherche a adapter son message, "Lumen vitae" 3 (1965) 546f.549f. 
"Whatever you did for one of the least of these brothers of Mine, you did for Me." This answer is characterized by universalism in the approach to man: no boundaries, no place, no time, no distinctions between people, no limitations as to the way or object of action: whatever you have done. Therefore, the field of the laity's activity cannot have any limitations: all that is needed is awareness of the contemporary state of affairs, the knowledge of the Gospel and a sense of responsibility for the Church established by Christ. From this, the appropriate internal attitude of the laity will grow, under the requirements of human nature and the precepts of the Gospel, as well as the deeds flowing from this point.

It seems that John Fitzgerald Kennedy accurately captures these moral aspects of the layman, the first Catholic president in the history of the United States of America, when he turned to the modern world with a question: "Can we create a world-wide grand alliance of North and South, East and West, which will create better living conditions for humanity?" The answer to this question was as follows: Let us begin. 